\title{
DETERMINATION OF FREE AND COMBINED PLANT ACIDS
}

\author{
Majja-Liisa Salo and Kajja Kotilainen \\ Department of Animal Husbandry, University of Helsinki
}

Received July 11, 1969

Organic acids are of great significance in plant and animal metabolism. The nonvolatile organic acids or plant acids (RANson 1965), as they are called in the book Plant Biochemistry, are of such abundance in many plant materials that they constitute an important taste factor. Examples among human foodstuffs are fruits and vegetables. The acids probably also affect the palatableness of animal forage; for instance, such palatable feeds as clover, roots and green tops are rich in acids. Moreover, plant acids are a noteworthy factor in the preparation of silage: the acids, which in the plant occur partly in a free state and partly as salts, form an efficient buffer system (PLAYNE \& McDonald 1966, Whittenbury et al. 1967).

Malic and citric acids are present in the highest concentrations in most vegetable materials (Hulme \& Richardson 1954, Playne \& McDonald 1966, Freeman 1967). Other acids found in larger quantities are quinic acid (Hulme \& Richardson 1954, Hirst \& Ramstad 1957, Jones \& Barnes 1967), glyceric acid (Lessard \& McDonald 1966, Playne \& McDonald 1966) and oxalic acid (Sanderson \& Selvendran 1965, Freeman 1967). Several acids occur in small quantities (WALL et al. 1961, Houston et. al 1963, Sanderson \& Selvendran 1965, Jones \& Barnes 1967). The most common cations associated with the plant acids are $\mathrm{K}^{+}, \mathrm{Na}^{+}, \mathrm{Ca}^{++}$and $\mathrm{Mg}^{+}$.

Individual plant acids are determined by chromatographic techniques. Separation and determination may be effected by gradient elution ion-exchange (WALL et al. 1961, Davies et al. 1965, Jones \& Barnes 1967) or silica gel chromatography (WALL et al. 1961, Sanderson \& Selvendran 1965, Lessard \& McDonald 1966). In addition to a knowledge of the sequence of the elution of the acids from the column, paper and thinlayer chromatography are taken as a basis for the identification (WALL et al. 1961, Davies \& Windsor 1967, Jones \& Barnes 1967). Gas-liquid chromatography has also been attempted in the determination of plant acids (Hautala 1966, Li \& Woodroof 1968). Detailed investigations of this kind offer a good picture of the plant acid compo- 
sition; nevertheless in routine work the procedures are complicated and can be applied in well-equipped laboratories only.

In this investigation attempts were made to develop a useful method for the determination of the total amount of plant acids occurring in a free state and as salts.

\section{PROPOSED SCHEME FOR THE DETERMINATION OF FREE AND COMBINED PLANT ACIDS}

\section{Principle}

The acids and salts are extracted with water att room temperature. A portion of the extract is used for the determination of the acidity by titration to $\mathrm{pH} 9$ ( = titratable acidity). From a second portion, the cations are retained by a strong cation exchanger using batch technique, whereupon the acidity is determined by titration to $\mathrm{pH} 9.0$. Since chlorides, phosphates and nitrates are also dissolved in the water and are converted by the cation exchanger into corresponding acids, the second titration-value is corrected accordingly. The remainder presents the total of plant acids. The cations are eluted from the ion exhanger with hydrochloric acid and determined by flame photometry. On the basis of the acid and cation equivalents, the total amount of plant acids, occurring in a free state and as salts, is calculated per g dry substance.

\section{Dissolving of acids}

$2 \mathrm{~g}$ of the powdered sample is put into an Erlenmeyer flask, and $100 \mathrm{ml}$ of cation-free water is added (distilled water treated in a cation-exchange column). The mixture is shaken mechanically for two hours, poured into a $200 \mathrm{ml}$ centrifuge tube, and centrifuged for 15-20 minutes at 3000 r.p.m. The liquid is sucked through a sintered-glass filter (porosity G2) into a suction flask. If the solution is kept overnight, a few drops of $0.01 \%$ Na-merthiolate should be added. The obtained solution (filtrate A) is used for the following determinations:

\section{Titratable acidity}

$25 \mathrm{ml}$ of the filtrate $\mathrm{A}$ is pipetted into a $250 \mathrm{ml}$ beaker and titrated electrometrically with $0.1 \mathrm{~N}$ sodium hydroxide to $\mathrm{pH} 9.0$. The result is calculated as mequiv./g drysubstance.

Total acidity, cations, and corrections for inorganic anions

$50 \mathrm{ml}$ of the filtrate A is pipetted into an Erlenmeyer flask and $1 \mathrm{~g}$ of Amberlite IR$120 \mathrm{H}^{+}$-resin added. The mixture is shaken mechanically for 30 minutes. The solution is then decanted into a $\mathrm{Gl}$ sintered glass funnel and filtered into a $200 \mathrm{ml}$ measuring flask, the major part of the ion-exchange granules remaining in the Erlenmeyer flask. The ion-exchange resin is then washed several times with small amounts of water and kept for the determination of the cations. The solution (filtrate B) is used in the following determinations:

A c id i t y. $100 \mathrm{ml}$ of the filtrate B is pipetted into a beaker and titrated to $\mathrm{pH} 9.0$ 
as described above. The total amount of plant acids is calculated from the consumption of $0.1 \mathrm{~N} \mathrm{NaOH}$, after correction for the inorganic anions present (see below).

Chloridecorrection. $1-2 \mathrm{ml}$ of a 10 per cent $\mathrm{K}_{2} \mathrm{CrO}_{4}$ solution is added to the previously mentioned neutralized solution, and the chloride content determined by titration with $0.05 \mathrm{~N} \mathrm{AgNO}_{3}$. A blank value, determined after the corresponding treatments, is substracted from the titration value obtained. The resulting figure corresponds to the amount of chlorides which have been converted to hydrochloric acid during the treatment in the cation exchanger. The result is calculated as mequiv. $\mathrm{HCl} / \mathrm{g}$ dry substance.

$\mathrm{Phosphate} \mathrm{correction.} \mathrm{The} \mathrm{P-content} \mathrm{of} \mathrm{filtrate} \mathrm{B} \mathrm{is} \mathrm{determined} \mathrm{for} \mathrm{a} 5 \mathrm{ml}$ sample as ammonium phosphomolybdate (KuTTNER \& Lichtenstein 1932), which is measured colorimetrically using a Beckman Model B spectrophotometer (wavelength $690 \mathrm{~m} \mu$, blue-sensitive phototube, red filter) or an EEL portable colorimeter. The result is calculated as mequiv. $\mathrm{H}_{3} \mathrm{PO}_{4} / \mathrm{g}$ dry substance. The correction used is two thirds of the value calculated, since at $\mathrm{pH} 9.0$ only two of the protons in phosphoric acid are dissociated.

$\mathrm{Nitrate}$ correction. The nitrate content of filtrate B is determined from a $20 \mathrm{ml}$ sample according to the method of Follet and Ratcliff (1963). The reduction with cadmium is effected in an ion-exchange column, and the colorimetric determination carried out at $474 \mathrm{~m} \mu$ using Beckman Model B spectrophotometer. The result is calculated as mequiv. $\mathrm{HNO}_{3} / \mathrm{g}$ dry substance.

The total amount of plant acids is arrived at by substraction of the $\mathrm{Cl}^{-}, \mathrm{PO}_{4}{ }^{--}$and $\mathrm{NO}_{3}{ }^{-}$-corrections from the total acidity milliequivalents.

Extract for chromatographic analysis. $25 \mathrm{ml}$ of filtrate $\mathrm{B}$ is evaporated to dryness in vacuo at a temperature of $40^{\circ} \mathrm{C}$. The residue is dissolved in $1 \mathrm{ml}$ of water containing a small amount of thymol. The resulting extract may be used for thin-layer or paper chromatographic analysis of the plant acid composition, and tested for the possible precence of galacturonic acid.

\section{Cations in the water extract}

The ion-exchange resin mass obtained during the course of the determination of the total acidity, now containing the retained cations, is transferred from the sintered glass funnel back to the Erlenmeyer flask by rinsing with $50 \mathrm{ml}$ of $3 \mathrm{~N} \mathrm{HCl}$. The mixture is shaken mechanically for 30 minutes, and filtered through the Gl glass-sinter into an evaporation bowl, avoiding as far as possible the passing of resin granules on the filter. $25 \mathrm{ml}$ of $3 \mathrm{~N} \mathrm{HCl}$ is added to the resin, the shaking is repeated for another 30 minutes, and the mixture is filtered through the same filter into the evaporation bowl. The filtrate is evaporated to dryness on a water bath, and the residue is dissolved and rinsed with four $5 \mathrm{ml}$ aliquots of $0.2 \mathrm{~N} \mathrm{HCl}$ into a small Erlenmeyer flask. The cations are determined from this solution, using a Beckman Model DU spectrophotometer equipped with a flame photometer. To the investigated solution is added such an amount of an appropriate buffer solution that the concentration of extraneous cations in the buffer exceeds that of the corresponding substances in the investigated solution. This is also done in conjunction with the construction of calibration curves by the aid of standard solutions. The buffer solutions contain potassium, sodium, calcium, magnesium and iron, respectively, as 
chlorides. The analysed solutions are diluted with $0.2 \mathrm{~N} \mathrm{HCl}$ to yield transmittance reading within the range $20-80$. If the reading is below 20 in the determination of $\mathrm{Ca}$, the accuracy can be improved by the addition of a fixed amount of a calcium chloride solution.

\section{RESULTS AND DISCUSSION OF PROPOSED METHOD}

\section{The behaviour of different acids and salts}

In connection with the ion-exchange treatment and titration the behavior of different acids and salts was studied. It was noted that in titration to $\mathrm{pH} 9.0$ the protons of all carboxyl groups in the most common plant acids dissociated almost completely. This is also the case with galacturonic acid. In the case of phosphoric acid, only two of the protons became dissociated; glutamic acid and aspargic acid dissociated to a minor extent only. Thus, the acids behaved in titration as could be expected on the basis of their pKvalues (Kolthoff \& Furman 1949).

It was noted that the accuracy of the titration could be much improved by using a $\mathrm{pH}$-meter instead of colour indicators. The equipment used was a Beckman pH-meter and an automatic burette.

Tests with pure salts disclosed that although the calcium salts of malic and citric acids dissolve in water only slowly, they may dissolve rather quickly in the water extract of the plant sample, on account of the acidity of the extract. Also $\mathrm{CaHPO}_{4}$ dissolves to some extent in the extract, but $\mathrm{Ca}_{3}\left(\mathrm{PO}_{4}\right)_{2}$ and calcium oxalate remain undissolved. The behaviour of the calcium salt of pectic acid was also going to be investigated; however, the only preparation available (FLukA, Phytic acid, Calcium salt) was too impure to yield any results. In the tests with pure salts it was noted that the solubility of slightly soluble salts was enhanced by the cation exchanger. Nevertheless, the acid contents obtained, when the plant samples were extracted with water and the cations then separately removed from the extract, were higher than in a treatment, where the cation exchanger was present during the extraction stage (Table 1). The former alternative was preferred for the proposed analytical procedure because of the higher values obtained and the shorter time required by the determination. Thus, according to the first alternative, titratable acidity, total acidity and cations can be determined from the same sample.

Several cation-exchange resins were tested for the retaining of the cations. All the strong sulphonic acid type cation-exchange resins tested yielded practically the same results as the resin chosen for the procedure. The weak carboxylic acid type resin, Amberlite IRC-50, was unsatisfactory, The resin chosen, Amberlite IR-120 (p.a., regenerated with $6 \mathrm{~N} \mathrm{HCl}$ ) has an exchange capacity of 4.5 mequiv./g. The amount used, $1 \mathrm{~g} / \mathrm{g}$ dry plant sample, therefore represents a considerable excess.

The water extract was in the beginning separated by filtration, but centrifugation was later preferred because of the low filtration rate of vegetables and fruits. The results obtained by centrifugation are generally slightly higher (Table 1), since in the filtrationalternative the washing is inevitably insufficient. In the proposed procedure the washing is omitted altogether; instead, the amount of water is measured accurately and the result calculated on the basis of the volume measured. This working stage is in fact simple as well as quick, and the repeatability of the results is good. 
Table 1. Examples of the total acid contents obtained after different extractions and filtrations. Values expressed as mequiv. per $1 \mathrm{~g}$ dry substance.

\begin{tabular}{llrl}
\hline & \multicolumn{3}{c}{ Extraction with water } \\
\cline { 2 - 4 } & $\begin{array}{c}\text { with cation } \\
\text { exchange }\end{array}$ & $\begin{array}{c}\text { without cation exchange } \\
\text { filtration }\end{array}$ \\
Cocksfoot & 1.284 & 1.488 & 1.491 \\
Cabbage & 1.133 & 1.245 & 1.273 \\
Leek & 0.681 & 0.773 & 0.781 \\
Bean & 1.021 & 1.053 & 1.063 \\
Parsley & 1.623 & 1.685 & 1.594 \\
Potato & 0.664 & 0.775 & 0.796
\end{tabular}

\section{Testing of the procedure for the determination of cations}

A series of tests were made with pure solution-mixtures containing $\mathrm{KH}_{2} \mathrm{PO}_{4}-\mathrm{Na}_{2} \mathrm{HPO}_{4}$ $-\mathrm{CaCl}_{2}-\mathrm{MgCl}_{2}$, to check the procedure for the determination of the cations. The solutions were treated in the same manner as were the water extracts of the plant samples. Examples of the results are presented in Table 2. It appears that one rinsing, after the elution-shaking treatment, is sufficient in the batch technique. However, the fact that the plant samples contain a large excess of potassium, in comparison with the other cations present, and that the amount of sodium is very minute, introduces complications in the determination. To determine the sodium and calcium, a 2-g sample must be taken; this means that a high dilution must be effected in conjunction with the determination of potassium. The tests disclosed that excessively high values were obtained at very low concentrations of $\mathrm{Na}^{+}, \mathrm{Ca}^{++}$and $\mathrm{Mg}^{++}$. The transmittance readings should range between 20 and $80 ; 30-70$ was taken as the objective. It seems that in the determination of potassium relatively satisfactory results are obtained even in the upper scale-region, as shown in example II of Table $2 . \mathrm{Na}^{+}$is the most difficult cation, the results obtained being systematically too high. Fixed amounts of calcium and sodium were also added to very dilute solutions to move the meter reading to a more accurate range. The example presented in Table 2 shows that for calcium this is a feasible approach, whereas in the case of sodium the result cannot be improved by it.

Two examples of the influence of phosphates upon the determination of the cations are furthermore given in Table 2. The measurements have been made direct on a phosphate solution. The results are in conformity with general experience (WENNER 1958); the Ca-value dropping down to an entirely wrong level in the presence of phosphates. The same trend, although weaker, can be noted for magnesium. On the other hand, potassium and sodium are determinable without error also in solutions containing phosphate. The good sodium-values obtained in these tests imply that the apparent surplus of sodium, noted previously, has been introduced as a contamination in connection with the cation-exchange treatment and eluate evaporation.

At the end of Table 2 some examples are given of parallel analyses of plant materials. The results, which were obtained on separate samples, display a sufficient repeatability.

The ion-exchange treatment was also compared with the ferric acetate treatment 
Table 2. Check of the procedure for the determination of cations. For explanations, see text.

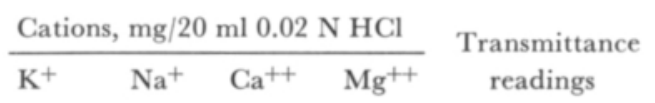

Pure phosphate solution No. 1 .

\begin{tabular}{|c|c|c|c|c|c|c|}
\hline Calculated & & 8.00 & 0.20 & 1.00 & 0.30 & \\
\hline \multirow[t]{4}{*}{ Found } & 1) & 7.98 & 0.25 & 1.00 & 0.32 & \multirow{3}{*}{$30-70$} \\
\hline & 2) & 8.02 & 0.29 & 0.93 & 0.33 & \\
\hline & 3) & 7.98 & 0.34 & 1.09 & 0.32 & \\
\hline & 1) & - & 0.35 & 1.39 & - & $<10$ \\
\hline \multirow{2}{*}{$\begin{array}{l}\mathrm{Na}^{+} \text {and } \mathrm{Ca}^{++} \\
\text {added }\end{array}$} & (1) & - & 0.30 & 1.00 & 一 & \multirow{2}{*}{$30-70$} \\
\hline & 2) & - & 0.37 & 0.94 & 一 & \\
\hline \multirow[t]{2}{*}{ Phosphates included } & 1) & 7.98 & 0.20 & 0.27 & 0.25 & \multirow{2}{*}{$30-70$} \\
\hline & 2) & 7.98 & 0.23 & 0.21 & 0.24 & \\
\hline \multicolumn{7}{|l|}{ Pure solution No. 2.} \\
\hline Calculated & & 25.2 & 1.53 & 5.00 & 0.50 & \multirow{3}{*}{$\begin{array}{l}\text { K: } 90-95 \\
\text { Others } 30-60\end{array}$} \\
\hline \multirow[t]{2}{*}{ Found } & 1) & 25.10 & 1.76 & 5.16 & 0.54 & \\
\hline & 2) & 26.56 & 1.93 & 4.89 & 0.58 & \\
\hline
\end{tabular}

Examples of plant analyses, $\mathrm{mg} / \mathrm{g}$ dry substance

\begin{tabular}{|c|c|c|c|c|c|c|}
\hline \multirow[t]{2}{*}{ Timothy } & 1) & 36.30 & 0.16 & 2.42 & 0.61 & \multirow{4}{*}{$20-80$} \\
\hline & 2) & 36.29 & 0.18 & 2.62 & 0.74 & \\
\hline \multirow[t]{2}{*}{ Bean } & 1) & 31.00 & 0.16 & 1.85 & 1.19 & \\
\hline & 2) & 30.62 & 0.14 & 1.78 & 1.17 & \\
\hline \multirow[t]{2}{*}{ Apple } & 1) & 9.09 & 0.10 & 0.49 & 0.32 & \\
\hline & 2) & 8.72 & 0.08 & 0.50 & 0.28 & \\
\hline
\end{tabular}

employed previously in this laboratory (MÄKELÄ 1967). In parallel tests with plant samples, the variations, especially in the determination of potassium and sodium, were far greater with the ferric acetate method; moreover, the sodium values were even higher than those obtained by the ion-exchange. The superiority of the ion-exchange method is probably due to its yielding a purer solution, and requiring a smaller number of error-inducing working stages. A saving of labour also appears to be an advantage of the ion-exchange method.

\section{The corrections for different anions}

During the development of the analytical procedure more correctives were examined than were incorporated into the final routine method, with a view to clarifying what substances occur in such concentrations that they would substantially affect the analysis results. It was established that there is no need to determine the amount of galacturonic acid. All the samples were tested for galacturonic acid by thin-layer chromatography (Ovodov et al. 1967), and found to be free from this substance. The result corresponded to what 
was anticipated on the basis of earlier investigation (SAlo 1965). - It was noted in preliminary tests that galacturonic acid would be quantitatively determined as acid in titration.

The acid amino acids, i.e. aspargic acid and glutamic acid, were found to induce such a small error that it did not call for an investigation of the amounts present in the water extract. Generally the pK-values of the amino acids are of such magnitude that the acids do not dissociate on titration to $\mathrm{pH} 9$ (Kolthoff \& Furman 1949).

A correction for nitrates was made in all the samples. However, the values were sufficiently small to permit the omission of the nitrate determination in routine work, since the procedure is rather laborious. For grasses grown on strongly fertilized pastures, a correction for nitrates is probably required.

All extracts were found to contain phosphorus, although the corresponding acidcorrection generally was below 0.2 mequiv./g dry substance. In the P-determinations, the Beckman B spectrophotometer and the EEL portable colorimeter were compared, using pure solutions. Good results were obtained with both meters. The repeatability was slightly better with the Beckman instrument, which was accordingly used in this investigation. However, the accuracy of the EEL colorimeter is fully satisfactory in routine work.

The chloride correction proved necessary, since rather large amounts of chlorides were present in many samples. Moreover, only a few minutes of extra work are required for the determination. The method used is not precise; nevertheless, after substraction of the blank value, the accuracy can be considered sufficient.

Sulphates were not investigated, since it was presumed that only very small amounts might be present. Neither were the carbonates investigated.

\section{DISCUSSION OF RESULTS OBTAINED WITH PLANT SAMPLES}

\section{Materials}

The results obtained with 17 plant materials are listed in Tables 3-5. Since the methodical questions were the primary concern of the investigation, the samples chosen were different fodders and foodstuffs. The major emphasis was laid on the latter group, as more plant acids are usually contained in greens than in fodders, and since the technical drawbacks of the analytical procedure become more easily evident with the vegetables and fruits. For example, it is easier to grind the sample, and to effect the filtrations, with roughage than with greens and apples.

The fodder samples were obtained from the Viik Experimental Farm; the branded foodstuff samples came from the Viik garden, and the others from the Helsinki vegetable market. All samples were promptly prepared and dried. Only the edible part of the foodstuffs was sampled; the potatoes, swedes, carrots and apples were husked, whereas the cucumbers were used unpeeled. The drying was effected either in a freeze-dryer or in a vacuum oven at $40^{\circ} \mathrm{C}$. The samples were ground, either in a Wiley mill with screen No. 40 , or in an IKA analysis-mill. The IKA mill is particularly useful in the preparation of sugar- and pectine-rich greens and fruits, which would readily clog the mill-screen. 
Table 3. Titratable and total acidity of some plant materials per $1 \mathrm{~g}$ dry substance.

\begin{tabular}{|c|c|c|c|c|c|c|c|c|c|}
\hline & \multicolumn{2}{|c|}{ Acidity, mequiv. } & \multicolumn{4}{|c|}{ Corrections, mequiv. } & \multicolumn{3}{|c|}{ Corrected total acidity } \\
\hline & $\begin{array}{c}\text { titra- } \\
\text { able } \\
\text { a }\end{array}$ & total & $\mathrm{HCl}$ & $2 / 3 \mathrm{H}_{3} \mathrm{P}$ & ${ }_{4} \mathrm{HNO}_{3}$ & $\begin{array}{c}\begin{array}{c}\text { total } \\
+\mathrm{d}+\mathrm{c}\end{array} \\
\mathrm{f}\end{array}$ & $\begin{array}{c}\text { mequiv. } \\
\mathrm{g}\end{array}$ & $\begin{array}{l}\text { f) } \\
\text { as malic } \\
\text { acid, } \\
\%\end{array}$ & $\begin{array}{c}\text { Percentag } \\
\text { of un- } \\
\text { correc- } \\
\text { ted value }\end{array}$ \\
\hline Cocksfoot, pasture stage & 0.21 & 1.49 & 0.52 & 0.14 & 0.01 & 0.67 & 0.82 & 5.5 & 55 \\
\hline Timothy, , , , & 0.23 & 1.20 & 0.31 & 0.17 & 0.01 & 0.49 & 0.71 & 4.8 & 59 \\
\hline Red clover $\quad, \quad$, & 0.34 & 1.86 & 0.30 & 0.13 & 0.01 & 0.44 & 1.42 & 9.5 & 76 \\
\hline Sugar beet tops & 0.17 & 2.25 & 1.40 & 0.09 & 0.02 & 1.51 & 0.74 & 5.0 & 33 \\
\hline Swede & 0.23 & 0.68 & 0.01 & 0.13 & 0.03 & 0.17 & 0.51 & 3.4 & 75 \\
\hline Potato, Akvila & 0.24 & 0.80 & 0.02 & 0.09 & 0.00 & 0.11 & 0.69 & 4.6 & 86 \\
\hline Carrot, Nantes & 0.21 & 0.81 & 0.08 & 0.09 & 0.02 & 0.19 & 0.62 & 4.2 & 77 \\
\hline Cabbage, Faales B. & 0.56 & 1.42 & 0.03 & 0.15 & 0.03 & 0.21 & 1.21 & 8.1 & 85 \\
\hline,$\quad$ Amager & 0.36 & 1.27 & 0.01 & 0.11 & 0.05 & 0.17 & 1.10 & 7.4 & 87 \\
\hline Leek, Københavnsk & 0.29 & 0.78 & 0.01 & 0.13 & 0.00 & 0.14 & 0.64 & 4.3 & 82 \\
\hline ,, Titan & 0.34 & 0.77 & 0.01 & 0.11 & 0.02 & 0.14 & 0.63 & 4.2 & 82 \\
\hline Bean, green & 0.39 & 1.06 & 0.03 & 0.13 & 0.04 & 0.20 & 0.86 & 5.8 & 81 \\
\hline Parsley & 0.37 & 1.59 & 0.05 & 0.18 & 0.01 & 0.24 & 1.35 & 9.0 & 85 \\
\hline Cucumber, green & 0.73 & 2.06 & 0.24 & 0.47 & 0.04 & 0.75 & 1.31 & 8.8 & 64 \\
\hline Tomato & 1.34 & 2.22 & 0.22 & 0.18 & 0.00 & 0.40 & 1.82 & 12.2 & 82 \\
\hline Apple, Wealthy & 0.84 & 1.04 & 0.00 & 0.03 & 0.00 & 0.03 & 1.01 & 6.8 & 97 \\
\hline Strawberry, Ydun & 1.78 & 2.30 & 0.02 & 0.07 & 0.01 & 0.10 & 2.20 & 14.7 & 96 \\
\hline
\end{tabular}

The proportions of the corrections in the analyses of different plant materials

Table 3 indicates the acid contents, and also the proportions of the corrections, related to the determinations of the total acidity.

It is noticeable that chlorides are abundant in gramineous plants, clover, and particularly in sugar beet tops. Against this, the chloride correction is very small in human food, with the exception of cucumber and tomatoes.

It can be noted that the P-correction varies rather little; its order of magnitude is $0.10-1.15$ mequiv./g dry substance. The nitrate correction is consistently so small that it can be omitted without introducing any serious error. From the sum of the corrections it appears that, owing to the high chloride content, the proportion of the corrections is much greater in fodder-plants than in human food. The extent, and particularly the type, of fertilization clearly exerts an influence upon the occurrence of certain inorganic anions in plants.

\section{Cations and combined acidity}

The amounts of water-soluble cations are given in Table 4 (in Table 5 also as $\mathrm{mg} / \mathrm{g}$ dry weight). In most materials, potassium makes up about $90 \%$ of the water-soluble cations. The exceptions are sugar beet tops and red clover, which are rich in sodium and calcium, respectively. The plant materials generally contain very small amounts of sodium, the sugar beet tops being the only exception among the plants studied. Since potassium and sodium occur mainly as water-soluble compounds (MÄKELÄ 1967), the 
figures for these cations represent their approximate total contents. The water-soluble calcium and magnesium in fodders corresponds to about half or more of the average total figures, respectively (Fodermiddeltabel 1969, MÄкELÄ 1967). Also in this respect the sugar beet tops make an exception (MÄKELÄ 1967), their calcium obviously occurring as insoluble oxalate. Since oxalic acid apparently also occurs as water-soluble K- and Na-salts, the percentage, calculated in Table 3 as malic acid, is too high for the sugar beet tops. On the other hand, the oxalic acid present as calcium oxalate has not been determined. Thus oxalic acid gives rise to inaccuracy and should be determined separately. In the materials studied here, the sugar beet tops obviously are the only ones rich in oxalic acid.

On the basis of the analyses a calculation was made of the proportion of plant acids occurring in a free and a combined state (as salts), respectively. In the calculations it has been presumed that the chlorides, phosphates and nitrates, as determined in the correctionprocesses, occur in plant materials quantitatively as salts. The remaining cations are considered to be bound as plant acid salts. The data presented in Table 4 indicate that in most of the plant materials studied the plant acids are predominantly in the salt form. However, in apples and strawberries the acids are mainly in a free form, as can be inferred also

Table 4. Water-soluble cations $(\mathrm{K}, \mathrm{Na}, \mathrm{Ca}, \mathrm{Mg})$ and free and combined plant acids per $1 \mathrm{~g}$ dry substance.

\begin{tabular}{|c|c|c|c|c|c|}
\hline \multicolumn{6}{|c|}{ Water-sol. cations, mequiv. } \\
\hline $\mathrm{K}^{+}$ & $\mathrm{Na}^{+}$ & $\mathrm{Ca}^{++}$ & $\mathrm{Mg}^{++}$ & total & combined with \\
\hline & & & & $a-d$ & $\begin{array}{c}\mathrm{Cl}^{\prime}+\mathrm{PO}_{4}{ }^{\prime \prime \prime} \text { plant } \\
+\mathrm{NO}_{3}{ }^{\prime} \text { 1) acids }\end{array}$ \\
\hline a & b & c & d & e & g \\
\hline
\end{tabular}
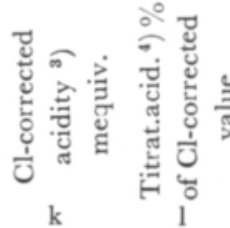

\begin{tabular}{lllllllllllll}
\hline Cocksfoot & 1.20 & 0.01 & 0.10 & 0.09 & 1.40 & 0.74 & 0.66 & 0.82 & 0.16 & 20 & 0.97 & 22 \\
Timothy & 0.93 & 0.01 & 0.13 & 0.06 & 1.13 & 0.57 & 0.56 & 0.71 & 0.15 & 21 & 0.89 & 26 \\
Red clover & 1.07 & 0.01 & 0.44 & 0.22 & 1.74 & 0.51 & 1.23 & 1.42 & 0.19 & 13 & 1.56 & 22 \\
Sugar beet tops & 1.44 & 0.56 & 0.04 & 0.15 & 2.19 & 1.56 & 0.63 & 0.74 & 0.11 & 15 & 0.85 & 20 \\
Swede & & & & & & & & & & & & \\
Potato & 0.45 & 0.01 & 0.05 & 0.07 & 0.58 & 0.24 & 0.34 & 0.51 & 0.17 & 33 & 0.67 & 34 \\
Carrot & 0.57 & 0.01 & 0.01 & 0.08 & 0.67 & 0.15 & 0.52 & 0.69 & 0.17 & 25 & 0.78 & 31 \\
& 0.68 & 0.03 & 0.02 & 0.04 & 0.77 & 0.23 & 0.54 & 0.62 & 0.08 & 13 & 0.73 & 29 \\
Cabbage, F. & 0.92 & 0.02 & 0.13 & 0.17 & 1.14 & 0.28 & 0.86 & 1.21 & 0.35 & 29 & 1.39 & 40 \\
$\quad, \quad$ A. & 0.81 & 0.02 & 0.21 & 0.07 & 1.11 & 0.22 & 0.89 & 1.10 & 0.21 & 19 & 1.26 & 29 \\
Leek, K. & 0.50 & 0.01 & 0.05 & 0.04 & 0.60 & 0.20 & 0.40 & 0.64 & 0.24 & 38 & 0.77 & 38 \\
$\quad$ T. & 0.49 & 0.01 & 0.06 & 0.03 & 0.59 & 0.19 & 0.40 & 0.63 & 0.23 & 37 & 0.76 & 45 \\
Bean & 0.79 & 0.01 & 0.09 & 0.10 & 0.99 & 0.27 & 0.72 & 0.86 & 0.14 & 16 & 1.03 & 38 \\
Parsley & 1.29 & 0.01 & 0.14 & 0.10 & 1.54 & 0.33 & 1.21 & 1.35 & 0.14 & 10 & 1.54 & 24 \\
Cucumber & 1.16 & 0.08 & 0.21 & 0.21 & 1.66 & 0.98 & 0.68 & 1.31 & 0.63 & 48 & 1.82 & 40 \\
Tomato & 1.16 & 0.03 & 0.04 & 0.14 & 1.37 & 0.51 & 0.86 & 1.82 & 0.96 & 53 & 2.00 & 67 \\
& & & & & & & & & & & & \\
Apple, W. & 0.23 & 0.00 & 0.02 & 0.02 & 0.27 & 0.04 & 0.23 & 1.01 & 0.78 & 77 & 1.04 & 81 \\
Strawberry, Y & 0.45 & 0.01 & 0.07 & 0.10 & 0.63 & 0.13 & 0.50 & 2.20 & 1.70 & 77 & 2.28 & 78
\end{tabular}

1) Table 3, columns $\mathrm{c}+\mathrm{e}+3 / 2 \mathrm{~d} \quad{ }^{2}$ ) Table 3, column ${ }^{3}$ ) Table 3, columns b-e $\quad$ i) Table 3, column a 
Table 5. The proportion of water-soluble cations in the total ash content.

\begin{tabular}{|c|c|c|c|c|c|c|c|}
\hline & \multirow{3}{*}{$\begin{array}{c}\text { Total ash } \\
\% \text { of } \\
\text { dry wt. }\end{array}$} & \multirow{2}{*}{\multicolumn{4}{|c|}{$\begin{array}{l}\text { Water-sol. cations } \\
\mathrm{mg} / 1 \mathrm{~g} \text { dry wt. }\end{array}$}} & \multicolumn{2}{|c|}{$\mathrm{K}+\mathrm{Na}+\mathrm{Ca}+\mathrm{Mg}$} \\
\hline & & & & & & \multirow{2}{*}{$\begin{array}{l}\mathrm{mg} / 1 \mathrm{~g} \\
\text { dry wt. }\end{array}$} & \multirow{2}{*}{$\begin{array}{r}\% \text { of } \\
\text { total ash }\end{array}$} \\
\hline & & $\mathrm{K}^{+}$ & $\mathrm{Na}^{+}$ & $\mathrm{Ca}^{++}$ & $\mathrm{Mg}^{++}$ & & \\
\hline Cocksfoot & 11.6 & 46.8 & 0.2 & 2.0 & 1.1 & 50.1 & 43 \\
\hline Timothy & 8.6 & 36.3 & 0.2 & 2.6 & 0.7 & 39.8 & 46 \\
\hline Red clover & 11.9 & 41.7 & 0.2 & 8.8 & 2.7 & 53.4 & 45 \\
\hline Sugar beet tops & 20.0 & 56.2 & 12.9 & 0.8 & 1.8 & 71.7 & 36 \\
\hline Swede & 4.3 & 17.6 & 0.2 & 1.0 & 0.8 & 19.6 & 46 \\
\hline Potato & 4.4 & 22.2 & 0.2 & 0.2 & 1.0 & 23.6 & 54 \\
\hline Carrot & 6.9 & 26.5 & 0.7 & 0.4 & 0.5 & 28.1 & 41 \\
\hline Cabbage, F. & 8.2 & 35.9 & 0.4 & 2.6 & 0.8 & 39.7 & 48 \\
\hline , , A. & 8.0 & 31.6 & 0.4 & 4.2 & 0.8 & 37.0 & 46 \\
\hline Leek, $\mathrm{K}$. & 4.6 & 19.5 & 0.2 & 1.0 & 0.5 & 21.2 & 46 \\
\hline,$\quad$ T. & 4.4 & 19.0 & 0.2 & 1.2 & 0.4 & 20.8 & 47 \\
\hline Bean & 6.5 & 30.8 & 0.2 & 1.8 & 1.2 & 34.0 & 52 \\
\hline Parsley & 10.6 & 50.3 & 0.2 & 2.8 & 1.2 & 54.5 & 51 \\
\hline Cucumber & 11.3 & 45.2 & 1.8 & 4.2 & 2.5 & 53.7 & 48 \\
\hline Tomato & 9.5 & 45.2 & 0.7 & 0.8 & 1.7 & 48.4 & 51 \\
\hline Apple, W. & 1.6 & 9.0 & 0.0 & 0.4 & 0.2 & 9.6 & 60 \\
\hline Strawberry, Y. & 4.0 & 17.6 & 0.2 & 1.4 & 1.2 & 20.4 & 51 \\
\hline
\end{tabular}

from their taste. Two strains of cabbage and leek were analysed for comparative purposes; for leek, the results agree very well, whereas for cabbage there are some differences. However, it should be pointed out that much larger deviations were noted between different berry and apple strains (unpublished data).

The contents of plant acids and particularly the plant acid salts are of significance in plant materials used for the preparation of silage. It is well-known that red clover cannot be as easily preserved as the Gramineae-plants, the reason being the high buffer capacity of clover (WhitTenbury et al. 1967). The large amounts of cations bound to the plant acids are of greater importance than a high acid content proper. When, in the silage, the plant acids are decomposed by micro-organisms, the cations are freed and able to neutralise the lactic and acetic acid formed. From Table 4 it appears that in red clover the amount of cations bound to be plant acids is about twice as large as in cocksfoot and timothy. Incidentally, the content of plant acids is also twice as large, and the acid to salt ratio is thus the same in these plants.

In the last colums of Table 4 a calculation has been made, on the basis of the data given in Table 3, of whether the chloride-corrected acidity, and the proportion of titratable acidity in it, agree with the results based on the three corrections and the cation determinations. This kind of determination could be made rapidly; also, knowledge concerning the contents of acids and salts would be of practical importance, for instance, in the preparation of silage. It appears that for many materials the results obtained by the rapid method agree approximately with those arrived at by a more complicated method. 


\section{Comparison with results reported in the literature}

Although this paper ends into a large number of references of which many are concerned with detailed separations and determinations of acids, very few publications seem to serve as suitable references. Thus very few papers are concerned with the calculation of the total acidity in those plant materials which have been investigated here. On the other hand, it is evident from published investigations that large deviations may occur in the acid and cation contents, respectively, even for a given plant species. Factors influencing this are, among others, the period of growth (FAuconNeAU \& Jarrige 1954, Hirst \& Ramstad 1957, Jones \& Barnes 1967), fertilization (especially K-fertilization) (Davies \& Windsor 1967, Freeman 1967), climatic conditions and strain (Lower \& Thomson 1966).

The largest number of comparisons can be made in respect of the gramineous plantsclover, tomato and various fruits. The gramineous plants contain organic acids $5.0-6.3 \%$ of dry substance according to ELY et al (1953). FAuconneau and Jarrige (1954) noted that the variation may range from 1.8 to $5.2 \%$ depending upon the growth period, and it can be calculated from the figures reported by Hirst and RAMSTAD (1957) that the sum of the four most abundant acids in rye-grass is $3.5-4.5 \%$. The total acid content of clover varies according to FAuconneau and JARrige (1954) from 5.3 to $7.8 \%$. The acid content of tomato varies greatly being dependent upon extrinsic factors and strain (Davies 1964, Lower \& Thomson 1966, Davies \& Windsor 1967). In comparison with the results of Lower and Thomson (1966) the sample investigated in this study belongs to the high-acid strains.

The acid contents of grasses and clover, as obtained in this investigation, are at the upper level in comparison with the references cited. However, all three analysed samples represent the early-summer growth period when the acid content is at its highest level. The different methods of analysis should also be taken in consideration; the method used is of significance even in the case of more easily determined substances than the plants acids.

\section{The proportion of water-soluble cations in the total ash content}

Table 5 indicates the weights of four cations per gramme of dry substance, and also their proportions in the total ash content. The figures indicate that both the ash and the cation contents may vary in different materials considerably; usually, the proportion of the water-soluble cations in the total ash amounts to $40-55$ per cent.

\section{$S u m$ m a r $y$}

A method is presented for the determination of the total amounts of plant acids and associated cations, viz. potassium, sodium, calcium and magnesium.

The principle of the method is as follows: The acids and salts are extracted into water, and the cations retained by an Amberlite IR $-120^{\mathrm{H}+}$ resin using a batch technique. The acids are titrated electrometrically to $\mathrm{pH}$ 9.0. The cations are eluted from the resin and determined by flame photometry. As the inorganic salts present in the water extract are converted by the ion exchanger to the corresponding acids, the total acidity value is corrected for the chlorides, phosphates and nitrates present. 
The free and combined plant acids are calculated on the basis of the results obtained.

The various stages of the analytical procedure are discussed and the results obtained in the analyses of 17 different fodders and foodstuffs are given as examples.

\section{REFERENCES}

Davies, C., Hartley, R. D. \& Lawson, G. J. 1965. Chromatographic behaviour of organic acids on Dower 1- x 10. J. Chromatogr. 18: 47-52.

DAvies, J. N. 1964. Effect of nitrogen, phosphorus and potassium fertilizers on the non-volatile organic acids of tomato fruit. J. Sci. Food Agric. 15: 665-673.

-,-_ \& Windsor, G. W. 1967. Effect of nitrogen, phosphorus, potassium, magnesium and liming on the composition of tomato fruit. Ibid. 18: 459-469.

Ely, R. E., Kane, W. C., Jacobson, W. C. \& Moore, L. A. 1953. A study of the crude fiber and nitrogenfree extract fractions of orchard grass hay and the digestibility of some of the constituents by milking cows. J. Dairy Sci. 36: 334-345.

Fauconneau, G. \& Jarrige, R. 1954. Organic acids in fodder plants, variations and attempted identification. European Grassland Conference 1954 p. 278-281.

Fodermiddeltabel, 1969. Nord. Jordbr. Forskn. 51, Nr 1.

Follett, M. J. \& RAtcliff, P. V. 1963. Determination of nitrite and nitrate in meat products. J. Sci. Food Agric. 14: 138-144.

Freeman, G. G. 1967. Studies on potassium of plants. II. Some effects of potassium deficiency on the organic acids of leaves. Ibid. 18: 569-578.

HaUtalA, E. 1966. Investigation of the gas-liquid chromatography of fruit acids. J. Ass. Off. Anal. Chem. 49: $619-621$.

Hirst, E. L. \& Ramstad, S. 1957. Changes in organic acid content of perennial rye-grass during conservation. J. Sci. Food Agric. 8: 727-732.

Houston, D. F., Hill, B. E., Garret, V. H. \& Kester, E. B. 1963. Organic acids of rice and some other cereal seeds. Agric. Food Chem. 11:512-517.

Hulme, A. C. \& Richardson, A. 1954. The non-volatile organic acids of grass. J. Sci. Food Agric.5: $221-225$.

Jones, E. C. \& Barnes, R. J. 1967. Non-volatile organic acids of grasses. Ibid. 18: 321-324.

Kolthoff, I. M. \& Furman, N. H. 1949. Potentiometric tirations. New York p. 449-450.

Kuttner, T. \& Lichtenstein, L. 1932. J. Biol. Chem. 95: 661 (ref. Moderne Methoden der Pflanzenanalyse I, S. 487. Berlin-Göttingen-Heidelberg 1956).

Lessard, J. R. \& McDonald, P. 1966. Silaca gel chromatographic procedure adapted to liquid-scientillation counting of ${ }^{14} \mathrm{C}$-labelled organic acids from plant material and silage. J. Sci. Food Agric. 17: 257-263.

LI, K. C. \& Woodroof, J. G. 1968. Gas chromatographic resolution of nonvolatile organic acids in peaches. J. Agric. Food Chem. 16: 534-535.

Lower, R. L. \& Thomson, A. E. 1966. Sampling variation of acidity and solids in tomatoes. Proc. Am. Soc. Hort. Sci. 89: 512-522.

Mäкelä, A. 1967. On the water-solubility of plant minerals. J. Sci. Agric. Soc. Finl. 39: 166-182.

Ovodov, Y. S., Eutushenko, E. V., Vaskovsky, V. E., Ovodova, R. G. \& Soloy'eva, T. F. 1967. Thin-layer chromaography of carbohydrates. J. Chromatogr. 26: 111-115.

Playne, M. J. \& McDonald, P. 1966. The buffering constituents of herbage and silage. J. Sci. Food. Agric. 17: 264-268.

Ranson, S. L. 1965. The plant acids. (Bonner, J. \& VArner, J. E.: Plant biochemistry, p. 493-525. New York-London 1965.)

SALO, M.-L. 1965. Determination of carbohydrate fractions in animal foods and faeces. Acta Agr. Fenn. 105: 1-102.

Sanderson, G. W. \& Selvendran, R. R. 1965 The organic acids in tea plants. A study of the non-volatile organic acids separated on silica gel. J. Sci. Food Agric. 16: 251-258. 
Wall, J. S., Swango, L. C., Tessari, D. \& Dimler, R. J. 1961. Organic acids of barley grain. Cereal Chem. 38: 407-422.

WenNer, V. R. 1958. Rapid determination of milk salts and ions. I. Determination of sodium, potassium, magnesium, and calcium by flame spectrophotometry. J. Dairy Sci. XLI: $761-768$.

Whittenbury, R., McDonald, P. \& Bryan-Jones, D. G. 1967. A short review of some biochemical aspects of ensilage. J. Sci. Food Agric. 18: 441-444.

\title{
SELOSTUS
}

\section{MENETELMÄ VAPAANA JA SUOLOINA ESIINTYVIEN KASVIHAPPOJEN MÄÄRITTÄMISEKSI}

\author{
Majja-Litsa Salo ja Kaja Kotilainen \\ Kotieläintieteen laitos, Helsingin yliopisto
}

Kirjoituksessa esitellään menetelmä kasvihappojen kokonaismäärän sekä happoihin liittyvien kaliumin, natriumin, kalsiumin ja magnesiumin määrittämiseksi.

Periaate määritysmenetelmässä on seuraava. Hapot ja suolat uutetaan veteen. Kationit sidotaan Amberlite IR-120 $\mathrm{H}+$-ioninvaihtajaan batch-menetelmällä. Hapot titrataan elektrometrisesti pH arvoon 9.0. Kationit eluoidaan ioninvaihtajasta ja määritetään liekkifotometrillä. Koska kationinvaihtaja muuttaa vesiliuoksessa olevat epäorgaaniset suolat vastaaviksi hapoiksi, tehdään titraustulokseen Cl-, P- ja $\mathrm{NO}_{3}$-korjaus. Tulosten perusteella lasketaan vapaana ja suoloina esiintyvä happomäärä.

Kirjoituksessa on menetelmän eri vaiheiden tarkastelua sekä esimerkkinä 17 rehu- tai ruoka-aineesta saadut analyysitulokset. Lisäksi siinä vertaillaan ko. yksityiskohtaisella menetelmällä ja sen vähätöisellä muunnoksella saatuja tuloksia. 